\title{
Microalgae and Cyanobacteria as a Source of Glycosidase Inhibitors
}

\author{
By RICHARD J. P. CANNELL, STEPHEN J. KELLAM, \\ ANIA M. OWSIANKA AND JOHN M. WALKER* \\ Algal Biotechnology Group, Division of Biological and Environmental Sciences, \\ The Hatfield Polytechnic, College Lane, Hatfield, Herts AL10 9AB, UK
}

(Received 6 February 1987; revised 24 February 1987)

Culture filtrates and organic solvent extracts of over 500 freshwater and marine eukaryotic microalgae and cyanobacteria were screened for the presence of glycosidase inhibitors. Rapid colorimetric assays were used to detect inhibitors of $\alpha$-glucosidase, $\alpha$-amylase and $\beta$ galactosidase. Inhibitors were found from 38 species. The results suggest that microalgae and cyanobacteria have potential as a source of glycosidase inhibitors which may have clinical applications.

\section{INTRODUCTION}

Many disease states are mediated by excessive enzyme activity, and inhibition of the enzymes involved could lead to treatment and control of the disease. Enzyme inhibitors have potential value therefore, as clinical tools. In the early 1960s, Umezawa began screening actinomycetes for the presence of enzyme inhibitors with a view to possible clinical or research use, and since then many dozens have been described (Umezawa, 1972, 1982). This screening has continued, but has concentrated mainly on the actinomycetes. It was decided to extend the search for potentially clinically useful enzyme inhibitors to a group of micro-organisms which in this respect are relatively unstudied - the microalgae. Like bacteria and fungi, microalgae are amenable to study under controlled batch culture conditions, where the effects of variation of chemical and physical parameters may be determined, and the production of any interesting compound optimized.

It has long been recognized that inhibition of glycosidases could be of value in the treatment and prevention of conditions such as diabetes, obesity, hyperlipoproteinaemia and hyperlipidaemia. These could all be better managed by controlling the kinetics of intestinal carbohydrate digestion and monosaccharide absorption, thus regulating blood sugar levels, insulin response, etc. The search for glycosidase inhibitors from natural sources has been going on for some time and many interesting and potentially valuable structures have been uncovered, e.g. acarbose and nojirimycin (Puls et al., 1977; Muller, 1985). Algae, particularly marine macroalgae, have been screened for antibiotic activity (Burkholder et al., 1960; Hornsey \& Hide, 1974; Pesando \& Caram, 1984; Reichelt \& Borowitzka, 1984), but not for enzyme inhibitors. We therefore decided to screen a range of eukaryotic microalgal and cyanobacterial culture filtrates and organic solvent extracts for the presence of inhibitors to $\alpha$-glucosidase, which hydrolyses $1,4-\alpha-$ glucosidic linkages, and rather more specifically, to $\alpha$-amylase, an endo-1,4- $\alpha$-glucanase acting on polymers, and also to $\beta$-galactosidase, which hydrolyses $1,4-\beta$-glucosidic linkages.

\section{METHODS}

Organisms. The algae and cyanobacteria were obtained mainly from the Culture Centre of Algae and Protozoa, Cambridge, UK. Approximately 300 freshwater and 200 marine eukaryotic algae, and 70 freshwater and 10 marine cyanobacteria, were cultured. All cultures were unialgal, but were not tested for axenicity. However, any obviously contaminated cultures were discarded. 
The freshwater eukaryotic algae were all grown in modified Chu 10, a minimal medium designed for autotrophic growth (Asher \& Spalding, 1982); many were also grown in M1, a nutrient-rich medium based on proteose peptone (Asher \& Spalding, 1982). The marine eukaryotic algae were all grown in medium M11, (Asher \& Spalding, 1982), and the cyanobacteria were all grown in medium BG-11 (Vonshak, 1986).

Cultures were inoculated from slopes into $250 \mathrm{ml}$ conical flasks containing $100 \mathrm{ml}$ medium, incubated at $23^{\circ} \mathrm{C}$, shaken at 100 r.p.m. with a $16 / 8 \mathrm{~h}$ (light/dark) photoperiod and a light intensity of $3000 \mathrm{~lx}$. The cultures were harvested after 6 weeks by centrifugation. The culture supernatant was decanted and the algal pellet extracted with methanol $(5 \mathrm{ml}$ per $\mathrm{g}$ wet weight, for $2 \mathrm{~h}$ ). The cells were then resedimented and the pellet was re-extracted in the same way with acetone and again with hexane.

Assays. The enzyme assays were done in microtitre plates and were based on the breakdown of a colorimetric substrate to produce a coloured product, enabling the reaction to be followed by measuring the absorbance over a period of time, at an appropriate wavelength, using an automatic ELISA plate reader. The enzyme and the test solution were preincubated to ensure maximum possible inhibition. Lack of colour development following the addition of substrate indicated enzyme-inhibitory activity. This system facilitated the simultaneous screening of many samples. Control samples of appropriate fresh media or methanol were included in all cases and inhibition of $50 \%$ or more was taken as a positive result. Duplicates of all samples were run. At the concentrations used here, the addition of methanol to the assay system did not appreciably affect the enzyme rate when compared to the rate obtained with fresh medium.

$\alpha$-Glucosidase. $\alpha$-D-Glucosidase [Sigma, type III, from yeast, suspension in $3 \cdot 2 \mathrm{M}-\left(\mathrm{NH}_{4}\right)_{2} \mathrm{SO}_{4}$ solution] was dissolved in $0.1 \mathrm{M}$-potassium phosphate, $3.2 \mathrm{mM}-\mathrm{MgCl}_{2}, \mathrm{pH} 6.8\left(0.1\right.$ units $\left.\mathrm{ml}^{-1}\right)$. The substrate was p-nitrophenyl $\alpha$-D-glucopyranoside dissolved in $0.1 \mathrm{M}$-potassium phosphate, $3.2 \mathrm{mM}-\mathrm{MgCl}_{2}, \mathrm{pH} 6.8$. To each well of a microtitre plate was added $25 \mu \mathrm{l} 0.5 \mathrm{M}$-potassium phosphate, $16 \mathrm{mM}-\mathrm{MgCl}_{2}, \mathrm{pH} 6.8 ; 100 \mu \mathrm{l}$ aqueous test solution, or $30 \mu \mathrm{l}$ methanolic (or acetone) extract and $70 \mu \mathrm{l}$ water; $50 \mu \mathrm{l}$ enzyme solution. This mixture was incubated at $37^{\circ} \mathrm{C}$ for $30 \mathrm{~min}$ and then $50 \mu \mathrm{l}$ substrate was added. The absorbance of the mixture at $410 \mathrm{~nm}$ was measured at time 0 and after incubation at $37^{\circ} \mathrm{C}$, when significant colour change had taken place (approx. $0.4 A_{410}$ units $^{-1}$ ).

$\alpha$-Amylase $\alpha$-Amylase (Sigma, type I-A, DFP-treated, from porcine pancreas, twice crystallized suspension in $2.9 \mathrm{M}-\mathrm{NaCl}$ solution containing $3 \mathrm{mM}-\mathrm{CaCl}_{2}$ ) was dissolved in $0.1 \mathrm{M}$-potassium phosphate, $0.05 \mathrm{M}-\mathrm{NaCl}, \mathrm{pH} 7 \cdot 1$ $\left(0.162\right.$ units $\left.\mathrm{ml}^{-1}\right)$. The substrate was one substrate tablet from a Boehringer $\alpha$-amylase PNP kit C-system, dissolved in $16 \mathrm{ml} 0.1 \mathrm{M}$-potassium phosphate, $0.05 \mathrm{M}-\mathrm{NaCl}, \mathrm{pH} 7 \cdot 1$. To each well of a microtitre plate was added: $25 \mu \mathrm{l} 0.5 \mathrm{M}$-potassium phosphate, $0.25 \mathrm{M}-\mathrm{NaCl}, \mathrm{pH} 7 \cdot 1 ; 100 \mu \mathrm{l}$ aqueous test solution, or $30 \mu \mathrm{l}$ methanolic (or acetone) extract and $70 \mu \mathrm{l}$ water; $50 \mu \mathrm{l}$ enzyme. This mixture was incubated at $37^{\circ} \mathrm{C}$ for $30 \mathrm{~min}$ and then $50 \mu \mathrm{l}$ substrate was added. The absorbance of the mixture at $410 \mathrm{~nm}$ was read at time 0 and again after incubation at $37^{\circ} \mathrm{C}$, when significant colour change had taken place (approx. $0.4 A_{410}$ units $\mathrm{h}^{-1}$ ).

$\beta$-Galactosidase. $\beta$-Galactosidase (Sigma, from Escherichia coli, suspension in $1.7 \mathrm{M}-\left(\mathrm{NH}_{4}\right)_{2} \mathrm{SO}_{4}, 10 \mathrm{~mm}-\mathrm{Tris}$ buffer salts and $1 \mathrm{mM}-\mathrm{MgCl}_{2}$ ) was dissolved in $0 \cdot 1 \mathrm{M}$-potassium phosphate, $16 \mathrm{~mm}-\beta$-mercaptoethanol, $9 \mathrm{~mm}$ $\mathrm{MgCl}_{2}, \mathrm{pH} 7 \cdot 3\left(0.017\right.$ units $\left.\mathrm{ml}^{-1}\right)$. The substrate was $\sigma$-nitrophenyl $\beta$-D-galactopyranoside dissolved in $0 \cdot 1 \mathrm{M}$ potassium phosphate $\mathrm{pH} 7.3\left(1.5 \mathrm{mg} \mathrm{m}^{-1}\right)$. To each well of a microtitre plate was added: $25 \mu \mathrm{l} 0.5 \mathrm{M}$ potassium

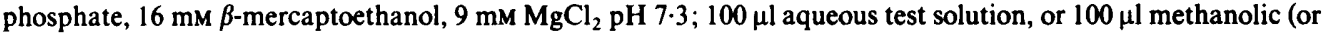
acetone) extract; $50 \mu \mathrm{l}$ enzyme solution. This mixture was incubated at $37^{\circ} \mathrm{C}$ for 30 min and then $50 \mu l$ substrate was added. The absorbance of the reaction mixture at $410 \mathrm{~nm}$ was read at time 0 and again after incubation at $37^{\circ} \mathrm{C}$ when significant colour change had taken place (approx. $0.4 A_{410}$ units $\mathrm{h}^{-1}$ ).

\section{RESULTS AND DISCUSSION}

From a total of over 500 cultures tested, 38 species gave rise to inhibition in one of the three assays (Table 1). More strains inhibited $\alpha$-glucosidase than $\alpha$-amylase, and only one case of inhibition of $\beta$-galactosidase was observed. One might expect the lists of algae producing inhibitors to $\alpha$-glucosidase and $\alpha$-amylase to overlap to a large degree, as both enzymes hydrolyse 1,4- $\alpha$-glucosidic linkages. However only three species appear on both lists. Evidently these enzymes, although hydrolysing the same bond by essentially the same mechanism, differ in their substrate specificity. It should also be noted that the enzymes used originated from different sources.

No one group of algae stands out as being particularly prolific in the production of inhibitory fractions, except perhaps the order Conjugales (of which a relatively small number were tested): culture extracts of six species were active against $\alpha$-glucosidase, and two of these were active against $\alpha$-amylase. Five different cultures of the cyanobacterial genus Oscillatoria produced inhibition of $\alpha$-amylase; it is possible that these closely related species produced the same, or at least closely related, active compounds. Most of the species producing inhibitors are members of 
Table 1. Algae and cyanobacteria producing inhibitors to $\alpha$-glucosidase, $\alpha$-amylase or $\beta$-galactosidase

CCAP

strain no.*

$265 / 1$

276/4B

$276 / 20$

Ire

$615 / 3$

$648 / 1 \mathrm{~A}$

$650 / 1$

$678 / 3$

$698 / 2$

$698 / 4$

$31 / 1$

$33 / 1$

$34 / 7$

Ire

Ire

$1414 / 1$

$1450 / 1$

$1453 / 26$

Ire

$505 / 9$

$702 / 1$

$80 / 1$

$19 / 1$

$19 / 9$

$11 / 34$

$1034 / 1$

$1052 / 6$

$933 / 25$

$66 / 6$

$961 / 3$

$1360 / 9$

$1360 / 11$
Solution

containing

inhibitor $\ddagger$
Percentage inhibition§

(a) Strains producing inhibitors to $\alpha$-glucosidase

Freshwater organisms

CHLOROPHYCEAE

Chlorococcales:

Pseudochlorella antarctica

Scenedesmus quadricauda

Scenedesmus subspicatus

Selenastrum minutum

C $\quad M$

C M

C

Conjugales:

Cylindrocystis brebisonii

Mesotaenium caldariorum

Mougeotia sp.

Spirogyra varians

Zygnema cylindricum

Zygnema sp.

C

$\mathbf{M}$

Tetrasporales:

Gloeocystis maxima

C

55

C

C

100

100

100

C

C

Volvocales:

Gloeomonas kupfferi

C

70

Haematococcus pluviatis

C

$\mathbf{M}$

55

CYANOBACTERIA

Anabaena spirodes

Anacystis nidulans

Coelosphaerium kuetzingianum

Microcystis aeruginosa

Nostoc sp.

Oscillatoria animalis

C

$\mathbf{M}$

Marine organisms

CHLOROPHYCEAE

Cladophorales:

Cladophora parriaudii

Aq

80

Siphonales:

Acetabularia acetabulum

S

Aq

100

Volvocales:

Asteromonas gracilis

$\mathbf{S}$

Dunaliella parva

Dunaliella parva

Dunaliella primolecta

Aq

100

M, Aq $\quad 100,85$

B

B

B

A

85

Aq $\quad 100$

A 100

Aq

100

BACILLARIOPHYCEAE

Gyrosigma spenceri

Phaeodactylum tricornutum

CHR YSOPHYCEAE

Ochromonas villosa

$\mathrm{Aq}$

100

$S$

Aq, $M$

100,95

Aq

95

S

Aq

100

S

Aq

90

S

Aq

100

PRASINOPHYCEAE

S

M

60

Tetraselmis rubens

S

Aq

100

PRYMNESIOPHYCEAE

Cricosphaera elongata

S

Aq

100

RHODOPHYCEAE

Audouinella parvula

Audouinella sp.

$\mathbf{S}$

M

55

Aq, M

100,50

(Table continued on next page) 
Table 1. (continued)

$\begin{array}{lccc}\text { CCAP } & \text { Growth } & \begin{array}{c}\text { Solution } \\ \text { containing } \\ \text { strain no.* }\end{array} & \begin{array}{c}\text { Percentage } \\ \text { inhibition } \S\end{array}\end{array}$

(b) Strains producing inhibitors to $\alpha$-amylase

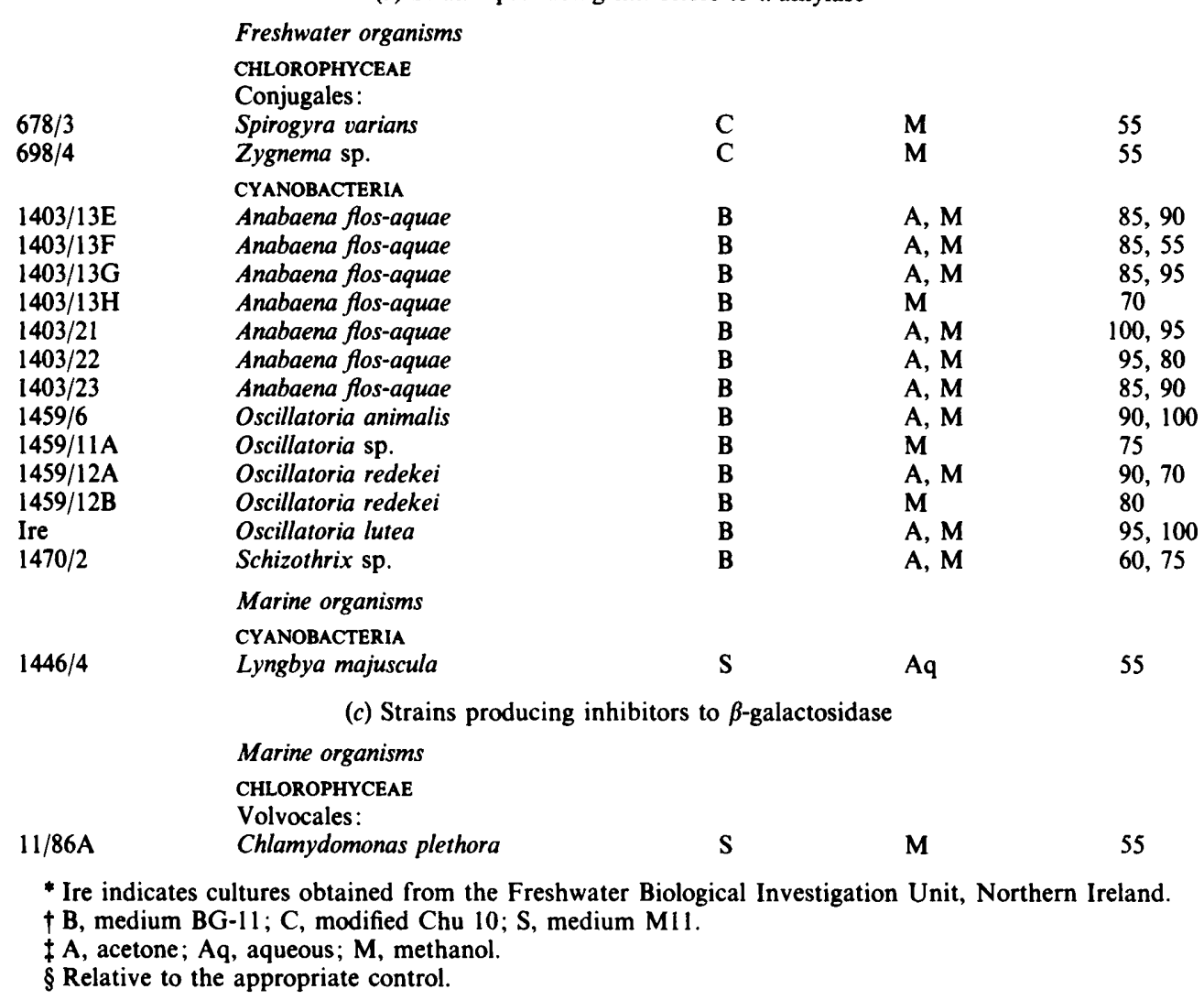

the Chlorophyceae, but this is probably simply because the Chlorophyceae was the largest group of algae tested, and the list of inhibitor-producing organisms included representatives from many of the algal classes (Table 1).

It is recognized that the experimental conditions used would not lead to the detection of all the inhibitors that could be produced. At the time of harvest, the cultures may not have reached the point at which they begin to produce inhibitors, and as the inhibitors are presumably mainly a result of secondary metabolism, different media and growth conditions might well give rise to different secondary products. This is borne out by the fact that none of the freshwater eukaryotic algae, the only group to be grown in two different media, produced inhibitors in both media. In fact, activity was only found from cultures grown in modified Chu 10.

Several of the species listed in Table 1, e.g. Anabaena flos-aquae and Microcystis aeruginosa, produce toxins and antibacterial compounds (Gorham, 1964), but to our knowledge no one has reported the existence of glycosidase inhibitors from algae or cyanobacteria. Our results show that these organisms are worthy of further study as a source of potentially useful glycosidase inhibitors. We are currently investigating the nature of the compounds involved.

The authors acknowledge financial support from the NAB Biotechnology Initiative, and R. J. P. Cannell acknowledges the receipt of an SERC studentship. We also thank Dr J. Baker of the Culture Centre of Algae and Protozoa, Cambridge, and Dr A. Fitzsimmons of the Freshwater Biological Investigation Unit, Northern Ireland. 


\section{REFERENCES}

Asher, A. \& Spalding, D. F. (editors) (1982). Culture Centre of Algae and Protozoa List of Strains. Cambridge: Institute of Terrestrial Ecology.

BURKHOLDER, P. R., BURKHOLDER, L. M. \& ALMODOVAR, L. R. (1960). Antibiotic activity of some marine algae of Puerto Rico. Botanica Marina 2, 149-156. Gorнам, P. (1964). Toxic algae. In Algae and Man, pp. 307-336. Edited by D. Jackson. New York: Plenum. HORNSEY, I. S. \& HIDE, D. (1974). The production of antimicrobial compounds by British marine algae. I. Antibiotic producing marine algae. British Phycological Journal 9, 351-363.

MULLER, L. (1985). Microbial glycosidase inhibitors. In Biotechnology, vol. 4, chapter 18. Edited by H.-J. Rehm \& G. Reed. Weinham: VCH Verlagsgesellschaft.

PESANDO, D. \& CARAM, B. (1984). Screening of marine algae from the French Mediterranean coast for antibacterial and antifungal activity. Botanica Marina 27, 381-386.
Puls, W., Keup, U., Krause, H. P., Thomas, G. \& HoFFMEISTER, F. (1977). Glucosidase inhibition (a new approach to the treatment of diabetes, obesity and hyperlipoproteinaemia). Naturwissenschaften 64 , 536-537.

Reichelt, J. L. \& BorowitzKA, M. A. (1984). Antimicrobial activity from marine algae : results of a large scale screening programme. Hydrobiologia 116-7, 158-168.

UMEZAWA, H. (1972). Enzyme Inhibitors of Microbial Origin. Tokyo: University of Tokyo Press.

UMEZAWA, H. (1982). Low molecular weight enzyme inhibitors of microbial origin. Annual Review of Microbiology 36, 75-79.

VoNSHAX, A. (1986). Laboratory techniques for the cultivation of microalgae. In CRC Handbook of Microalgal Mass Culture, pp. 117-145. Edited by A. Richmond. Boca Raton, Florida: CRC Press. 